Martínez-Pérez et al., Afr J Tradit Complement Altern Med., (2017) 14 (4): 62-68

https://doi.org/10.21010/ajtcam.v14i4.8

\title{
IN VIVO EFFECT OF RUTA CHALEPENSIS EXTRACT ON HEPATIC CYTOCHROME 3A1 IN RATS
}

\author{
Edith Fabiola Martínez-Pérez ${ }^{a^{*}}$, Fernando Hernández-Terán ${ }^{\mathrm{b}}$ and Luis Benjamín Serrano-Gallardo ${ }^{\mathrm{a}}$ \\ ${ }^{a}$ Centro de Investigación Biomédicas (CIBM), Universidad Autónoma de Coahuila, Facultad de Medicina,

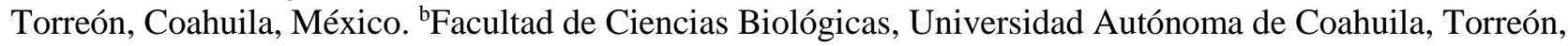 \\ Coahuila, México.
}

*Corresponding Author E-mail: e_fabiolamtz@yahoo.com.mx

\begin{abstract}
Background: Since the time when drugs began to be used, it became evident that they could produce a therapeutic effect, but also a clinical condition of toxicity or no effect at all on humans, despite using the same doses in different patients. Such untoward effects were termed "drug idiosyncrasy" and also "idiosyncratic drug effects", but the factors producing such diverse responses were never taken into account.

Materials and Methods: Ruta chalepensis L. (fringed rue) is an herbaceous plant of the Rutaceae family used in traditional medicine due to its properties, such as its analgesic and antipyretic effects. This study used 25 male rats divided into five groups. Plant extract was administered to Groups 1 and 2 at doses of 100 and $30 \mathrm{mg} / \mathrm{kg} / \mathrm{day}$, respectively, for three days; Group 3 was administered $100 \mathrm{mg} / \mathrm{kg} /$ day of dexamethasone (DEX), as well as $100 \mathrm{mg} / \mathrm{kg} / \mathrm{day}$ of Ruta chalepensis extract; Group 4 was administered $100 \mathrm{mg} / \mathrm{kg} / \mathrm{day}$ of DEX and treated as positive control; Group 5 was treated as negative control and was administered a physiological solution. Twenty-four hours after the the last dose, the animals were sacrificed and their livers were extracted.

Results: The aqueous extract of Ruta chalepensis, intraperitoneally administered, was able to induce cytochrome $3 \mathrm{~A} 1$ in doses of $30 \mathrm{mg} / \mathrm{kg} / \mathrm{day}$, and a greater inducing effect occurs when the plant is co-administered in doses of $100 \mathrm{mg} / \mathrm{kg} / \mathrm{day}$ with dexamethasone.

Conclusion: This study suggests that aqueous extract of Ruta chalepensis can induce cytochrome 3a1. This study helps provide a better understanding of CYP3a regulation. Future in vitro work is needed to determine the compounds that produce the cytochrome modulation.
\end{abstract}

Keywords: CYP3a; R. chalepensis; Wistar; qRT-PCR; Microplates, Artemia

\section{Introduction}

Cytochrome $\mathrm{P}_{450}\left(\mathrm{CYP}_{450}\right)$ enzymes belong to a superfamily of hemoproteins that play an important role in the metabolism of endogenous as well as exogenous compounds, such as drugs of clinical importance, carcinogens, steroids, and cholesterol (Liu, 2010; Sarkar et al., 2003). These enzymes are also charged with metabolizing thousands of bioactive compounds of plants with very diverse chemical structures (Laursen et al., 2011). These enzymes are the main mechanism for increased, diminished, or null bioavailability of herbal-based drugs and compounds when said enzymes and drugs are simultaneously administered (Pekthong et al., 2009; Wang et al., 2009). They are termed P450 because an absorbance peak is produced at $450 \mathrm{~nm}$ when treated with a reducer agent and linked with carbon monoxide (Pan et al., 2011). In rats, the CYP450 enzymes commonly involved in the metabolism of xenobiotics include CYP1a2, CYP2c11, CYP2e1, and CYP3a1/2 (Li et al., 2008), while in humans, the enzymes involved are CYP1A2, CYP2C9, CYP2D6, and CYP3A4 (Ponnusankar et al., 2011; Zhou et al., 2011). The overexpression of CYP3A4 has been reported to contribute to the development of leukemia, prostate cancer, and breast cancer (Keshava et al., 2004). A decrease in CYP3A4 overexpression appears to reduce the risk of cancer in children (Swinney et al., 2006). In rats, the CYP3A subfamily is the second in importance, followed by Cytochrome 2C11, with an abundance of 39\%; however, the CYP3A subfamily is responsible for metabolizing 50-60\% of all currently employed drugs: it is thus the most important and abundant enzyme in the human organism (Dally et al., 2003; Zhou et al., 2007). CYP3A is expressed mostly in the liver and the gastrointestinal tract (Chen et al., 2009). People tend to combine different plant preparations with modern prescription drugs, in that they consider it safe to consume herbal derivatives; such combinations can produce plant-drug interactions (Pekthong et al., 2009). Ruta chalepensis ( $R$. chalepensis) is native to southern Europe and the Eastern Mediterranean region, where it is known as Ruda; this plant is cultivated in the greater part of the American continent. By virtue of its analgesic and antipyretic effects, it has 62 


\section{Martínez-Pérez et al., Afr J Tradit Complement Altern Med., (2017) 14 (4): 62-68}

https://doi.org/10.21010/ajtcam.v14i4.8

been used in the treatment of neuralgia, rheumatism, and menstrual disorders (al-Said et al., 1990), as an abortive and antirheumatic, for intestinal and hepatic diseases, as an antiepileptic and antipyretic, it is also useful in perfumery, and it has insecticidal activity (Pino et al., 2014; Di Stasi et al., 1994). Phytochemical screening of $R$. chalepensis has shown the presence of campherol, rutin, quercetin, bergapten, chalepsin, psoralen, skimmianine, kokusaginine, graveoline, furoquinoline, $\gamma$-fagarine, dictamnine, arborinine, and chalepensin (Schmelzer and Gurib-Fakim, 2013), as well as coumarins, which are employed in the treatment of the symptoms of multiple sclerosis (Orlita et al., 2008). Flavonoids, glycosides, and tannins are considered potent pro-inflammatory molecule inhibitors. In this study, we employed the aqueous-type $R$. chalepensis extract used by popular medicine in the form of an infusion and/or decoction from the plant (Khadhri et al., 2017).

\section{Materials and Methods \\ Preparation of the aqueous extract of $R$. chalepensis}

Five $\mathrm{kg}$ of fresh $R$. chalepensis plant specimens were acquired in the North of Mexico (25.53607 N, 103.52117 $\mathrm{W})$. The plant material was dried for 10 days at room temperature. The aerial parts were ground to a fine powder. One hundred $\mathrm{g}$ of fresh powder was weighed, and $1,000 \mathrm{~mL}$ of distilled water was added; the mixture was heated to $100^{\circ} \mathrm{C}$, shaken for $1 \mathrm{~h}$, and then filtered with Whatman $\mathrm{N}^{\circ} 1$ filter paper using a vacuum pump. The filtrate was taken to dryness in a furnace set at $40^{\circ} \mathrm{C}$ to obtain the dry extract, which was stored at $5^{\circ} \mathrm{C}$ in the dark until it was used. A voucher specimen of Ruta chalepensis, numbered 60663, was deposited in the Herbarium of the Benemérita Universidad Autónoma de Puebla (BUAP), Mexico.

\section{In vivo study with Wistar rats}

We placed 25 male 11-week old Wistar rats in five cages, five animals per cage. The weights of the rats were between 250 and $300 \mathrm{~g}$. For seven days prior to the treatment, the rats were maintained under standard laboratory conditions (temperature $24^{\circ} \mathrm{C}, 12$-h light/dark cycles, $45 \%$ relative humidity) with ad libitum access to pellets $\left(\mathrm{Teklad}^{\circledR}\right.$ $18 \%$ protein) and water. None of the animals was replaced during the study. The experimental protocol was approved by the Bioethics Committee of the Universidad Autónoma de Coahuila, Facultad de Medicina, in Mexico, with approval number 0100-10. The rats were treated via intraperitoneal (i.p.) injection with 100 and $30 \mathrm{mg} / \mathrm{kg} / \mathrm{day}$ of $R$. chalepensis extract, respectively, for groups 1 and 2. Another group was administered $100 \mathrm{mg} / \mathrm{kg} / \mathrm{day}$ of Dexamethasone (DEX) combined with $100 \mathrm{mg} / \mathrm{kg} /$ day of $R$. chalepensis extract. As a positive control, one group was administered $100 \mathrm{mg} / \mathrm{kg} / \mathrm{day}$ of DEX. We employed saline solution $(0.9 \%)$ as vehicle with all of the groups at a dose of $6.67 \mathrm{~mL} / \mathrm{kg} / \mathrm{day}$, with the exception of the positive control group, which was administered corn oil $(6.67 \mathrm{~mL} / \mathrm{kg} / \mathrm{day})$ for 3 consecutive days. After the last administration session, all rats were fasted for $24 \mathrm{~h}$, were then anesthetized with ether, sacrificed, and their livers were extracted; the liver tissues were placed in RNALater ${ }^{\circledR}$ until they were processed.

\section{Extraction of messenger RNA (mRNA)}

Livers were cut into 3-mm-thick slices, which were submerged in RNALater ${ }^{\circledR}$ (Qiagen ${ }^{\circledR}$, USA); these samples were stored at $4^{\circ} \mathrm{C}$ for $24 \mathrm{~h}$ for RNase inactivation, and were later frozen at $-20^{\circ} \mathrm{C}$ until they were processed. The mRNA was isolated utilizing the RNeasy Protect Mini Kit (Qiagen ${ }^{\circledR}$, USA), following the manufacturer’s instructions.

\section{Real-time quantitative PCR, Reverse Transcription, and qPCR (qRT-PCR)}

We employed the primers 5'-TTCACCGTGATCCACAGCA-3' and $3^{\prime}$-TGCTGCCTTGTTCTCCTT-5' of CYP3a1; these were confirmed in GenBank with access number L24207; as control, we utilized GAPDH (Taqman ${ }^{\circledR}$ Rn01775763_g1) ((Morioka et al., 2006).

For amplification, we used TaqMan ${ }^{\circledR}$ catheters with 50 denaturation cycles of $15 \mathrm{sec}$ at $92^{\circ} \mathrm{C}$. Hybridization was carried out for $90 \mathrm{~min}$ at $60^{\circ} \mathrm{C}$. The qRT-PCR reaction was developed using Applied Biosystem $7300^{\circledR}$ equipment and the Techne ${ }^{\circledR}$ Thermocycler. 


\section{Martínez-Pérez et al., Afr J Tradit Complement Altern Med., (2017) 14 (4): 62-68}

https://doi.org/10.21010/ajtcam.v14i4.8

\section{Toxicity test in microplates}

In order to calculate the median Lethal Dose $\left(\mathrm{LD}_{50}\right)$, we employed the Artemia salina larval bioassay (San Francisco Bay Brand Brine Shrimp Eggs ${ }^{\circledR}$ ); we placed $20 \mathrm{~g}$ of cysts in $500 \mathrm{~mL}$ of Instant Ocean ${ }^{\circledR}$ Sea Salt, and the pH value was adjusted to 7.8 for cyst incubation at a temperature of $22-25^{\circ} \mathrm{C}$ for $48 \mathrm{~h}$ under a white light lamp. After this, we prepared dilutions of $50,125,250,750$, and $1,000 \mathrm{ppm}$. We inserted 10 nauplii per well, and $24 \mathrm{~h}$ later, we counted the dead and live nauplii. In the toxicity bioassay, larvae were considered dead when no movement was observed after observation for a number of seconds (Carballo et al., 2002). The calculation of $\mathrm{LD}_{50}$ was obtained using Minitab software (v. 15.0 for Windows; State College, PA, USA). The toxicity criteria employed are in agreement with those utilized by Bastos et al. (2009) and Déciga-Campos et al. (2007), where $\mathrm{LD}_{50}$ values $>1,000 \mu \mathrm{g} / \mathrm{mL}$ are non-toxic, values $\geq 500$ and $\leq 1,000 \mu \mathrm{g} / \mathrm{mL}$ have weak toxicity, and values $<500 \mu \mathrm{g} / \mathrm{mL}$ are toxic.

\section{Statistical analysis}

Difference between groups was obtained using the non-parametric Mann-Whitney $U$ analysis. The $\mathrm{LD}_{50}$ was determined by linear regression analysis using the SPSS Science statistical software (v. 15.0 for Windows; SPPS, Inc., Chicago, IL, USA), as well as GraphPad Prism (v. 5.0 for Windows; San Diego, Ca, USA), and Minitab (v. 15.0 for Windows; State College, PA, USA). The significance level was established at $p<0.05$.

\section{Results}

\section{Effect of the treatment with aqueous extract of Ruta chalepensis on Wistar rats}

Body Weight (BW) was not affected by the treatment (data not shown). Tables 1 and 2 present the mRNA levels obtained from the treatment groups in comparison with the control group, which was treated with saline solution only. Treatment for 3 consecutive days with DEX ( $100 \mathrm{mg} / \mathrm{kg} /$ day) caused an inducer effect 9.94 -fold that of cytochrome; in the treatment groups, the effect was inversely proportional to the concentration of the extract employed, producing a 0.93 -fold decrease with regard to the control in the group in which Ruta chalepensis was administered at $100-\mathrm{mg} / \mathrm{kg}$ doses, and a 2.06-fold enzymatic induction increase in the group that was administered $30-\mathrm{mg} / \mathrm{kg}$ doses of aqueous extract. In the third group ( $R$. chalepensis plus DEX, both at $100-\mathrm{mg} / \mathrm{kg} /$ day doses), there was a 5.84 -fold increase in comparison with the saline solution group (Figure 1; Figure 2).

Table 1: Fold change of messenger RNA (mRNA) as a result of intraperitoneal (i.p.) administration of aqueous extract of Ruta chalepensis for 3 consecutive days $(n=25)^{\mathrm{a}}$.

\begin{tabular}{llll}
\hline Treatment & Times of change & 95\% CI & $P$ \\
\hline $\begin{array}{l}\text { Saline solution } \\
(6.67 \mathrm{~mL} / \mathrm{kg} / \mathrm{day})\end{array}$ & $1.643 \pm 1.034$ & $0.358 \pm 2.928$ & \\
\hline $\begin{array}{l}\text { Dexamethasone } \\
\text { mg/kg/day) }\end{array}$ & $9.949 \pm 2.599$ & $6.722 \pm 13.18$ & \\
\hline $\begin{array}{l}\text { R. chalepensis } \\
\text { (100 mg/Kg/day) }\end{array}$ & $0.715 \pm 0.843$ & $-0.332 \pm 1.763$ & 0.310 \\
\hline $\begin{array}{l}R . \text { chalepensis } \\
\text { (30 mg/Kg/day) }\end{array}$ & $3.702 \pm 1.432$ & $1.923 \pm 5.480$ & $0.032^{*}$ \\
\hline $\begin{array}{l}\text { \& Dexamethasone and } \\
\text { R. chalepensis }\end{array}$ & $7.486 \pm 2.538$ & $4.335 \pm 10.64$ & $0.008^{*}$ \\
\hline
\end{tabular}

${ }^{a}$ Results are expressed as mean \pm Standard Deviation (SD). * Mann-Whitney $U$ test $(p<0.05)$, with respect to the saline solution. ${ }^{\&} R$. chalepensis plus DEX, both at $100-\mathrm{mg} / \mathrm{kg} /$ day doses. 
Martínez-Pérez et al., Afr J Tradit Complement Altern Med., (2017) 14 (4): 62-68

https://doi.org/10.21010/ajtcam.v14i4.8

Table 2: Quantification of mRNA levels in Wistar rat liver as a result of intraperitoneal (i.p.) administration of aqueous extract of Ruta chalepensis for 3 consecutive days $(n=25)^{\mathrm{a}}$

\begin{tabular}{lc}
\hline Treatment & Media \pm DE $(\boldsymbol{\mu L} / \mathbf{n g})$ \\
\hline Saline solution $(6.67 \mathrm{~mL} / \mathrm{kg} /$ day $)$ & $29 \pm 1.6^{*}$ \\
\hline $\begin{array}{l}\text { Dexamethasone } \\
(100 \mathrm{mg} / \mathrm{kg} / \text { day })\end{array}$ & $23 \pm 2.0^{*}$ \\
\hline $\begin{array}{l}\text { R. chalepensis } \\
(100 \mathrm{mg} / \mathrm{Kg} / \mathrm{day})\end{array}$ & $26 \pm 1.0$ \\
\hline $\begin{array}{l}\text { R. } \text { chalepensis } \\
(30 \mathrm{mg} / \mathrm{Kg} / \mathrm{day})\end{array}$ & $25 \pm 2.1^{*}$ \\
\hline $\begin{array}{l}\text { \& Dexamethasone and } \\
\text { R. chalepensis }\end{array}$ & $20 \pm 1.2^{*}$ \\
\hline
\end{tabular}

${ }^{\text {a }}$ Results are expressed as mean \pm Standard Deviation (SD). Post Hoc Tukey ( $\left.<<0.05\right)$, with respect to the saline solution. ${ }^{\&}$ R. chalepensis plus DEX, both at $100-\mathrm{mg} / \mathrm{kg} /$ day doses.

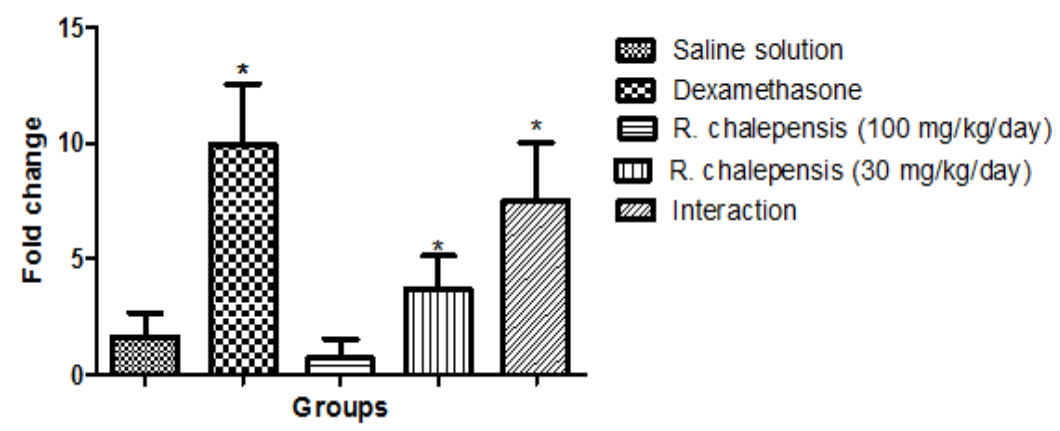

Figure 1: Effect of the aqueous extract of Ruta chalepensis on the expression of messenger RNA (mRNA) of CYP3a1 in Wistar rat $(n=25)$ after $72 \mathrm{~h}$ of treatment. Results aree expressed as the number of times of change compared with the control group ( $\mathrm{n}=5)$, which was administered saline solution. Interaction: Ruta chalepensis $(100 \mathrm{mg} / \mathrm{kg} / \mathrm{day})$ plus Dexamethasone (DEX) $(100 \mathrm{mg} / \mathrm{kg} /$ day $)$.

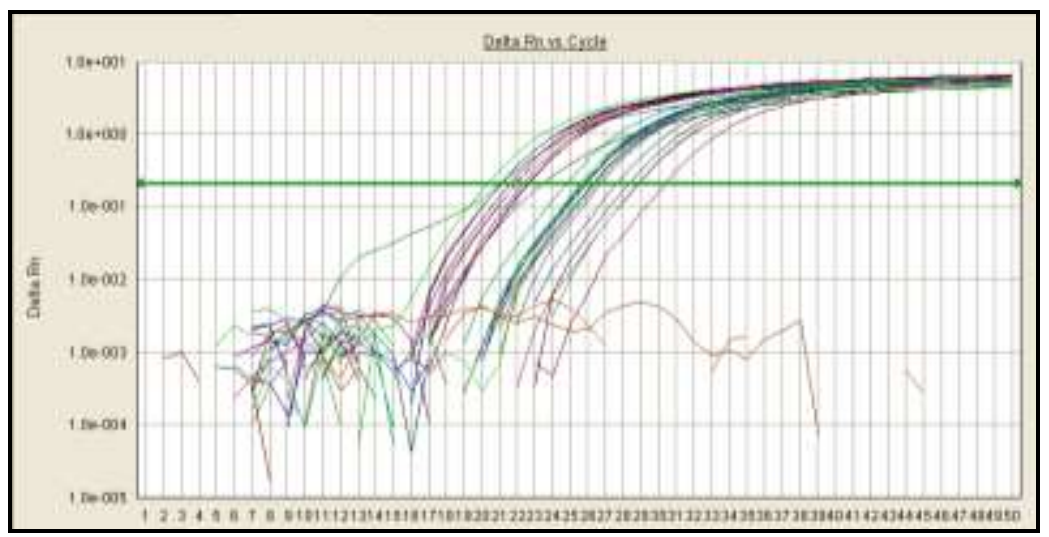

Figure 2: Real-time PCR amplification plot. 
Martínez-Pérez et al., Afr J Tradit Complement Altern Med., (2017) 14 (4): 62-68

https://doi.org/10.21010/ajtcam.v14i4.8

\section{Toxicity Test on Microplate}

There was a dose-response relationship reflected by a linear regression graph (Figure 3); the median Lethal Dose $\left(\mathrm{LD}_{50}\right)$ calculated was $109.93 \mu \mathrm{g} / \mathrm{mL}$.

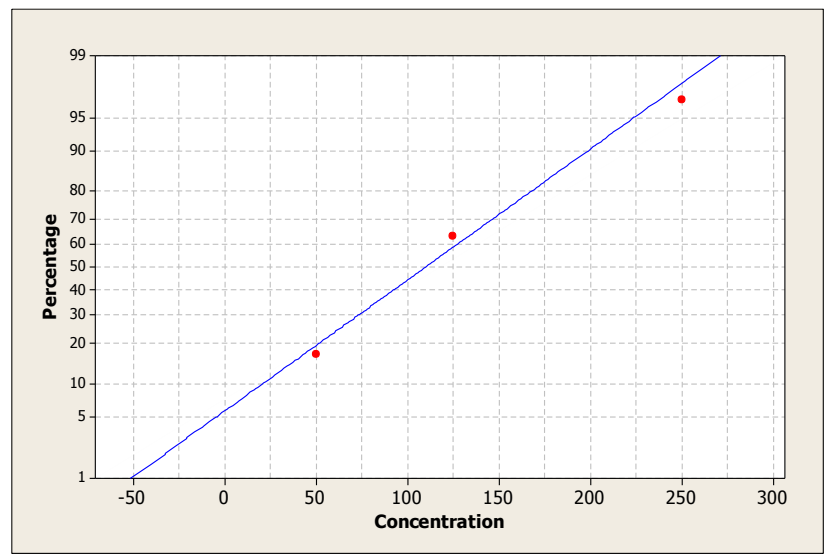

Figure 3: Transformation of the percentage of mortality of Artemia salina for the aqueous extract of Ruta chalepensis. Each point represents the mean of three repetitions per dose. The median Lethal Dose $\left(\mathrm{LD}_{50}\right)$ calculated was $109.93 \mu \mathrm{g} / \mathrm{mL}$.

\section{Discussion}

The drug-plant interactions produced by cytochrome P450 (CYP450) have been widely studied; thus, these interactions could attain clinical significance. In view of the toxicity evaluation results obtained by the Artemia salina assay, the aqueous extract of $R$. chalepensis was found to be toxic. This result coincides with other reports indicating that methanolic and aqueous extracts of Ruta graveolens are toxic at $\mathrm{LD}_{50}$ values $<100 \mu \mathrm{g} / \mathrm{mL}$ (Serrano-Gallardo, 2005). The present study evinced the capacity of the aqueous extract of $R$. chalepensis in modulating the expression of mRNA of CYP450. In 2005, de Freitas et al. evaluated the effect of $R$. graveolens methanolic extract for 15 days via oral route in $1,000-\mathrm{mg} / \mathrm{kg}$ doses in mice, concluding that this plant can damage diverse organs; therefore, $R$. graveolens should not be employed as a medicinal plant. On the other hand, Lee et al. (2011) conducted a study on the use of tanshinones against cancer via chemoembolization. Thus, it is important to know the type of cytochrome modulation via injectable extract route.

This study was focused on CYP3a, one of the main enzymes in the metabolization process of currently produced drugs (Mrozikiewicz et al., 2010). Previous research has reported on the assessment of different solvents used to obtain $R$. chalepensis extract; its authors have concluded that the aqueous extract contains the greatest amount of constituents and cancels the risk of ethanol, hexane, or another type of solvents interacting with the plant's constituents, which cause an effect on the cytochromes under study (Nazish et al., 2009). This is a possible explanation to the results found by Pan et al. (2011), who concluded that the petroleum ether (PE) extract of Orthosiphon stamineus produces the greatest inhibitor effect on CYP2C19. At the time this experiment was published, there were no other studies on $R$. chalepensis extract in cytochromes available to compare our results; however, previous research reports on the study of other plants, such as Andrographis paniculata (Pekthong et al., 2009), Orthosiphon stamineus, Aframomum cuspidatum (Agbonon et al., 2010), and Centella asiatica (Pan et al., 2011) in cell culture. Centella asiatica was also studied in vivo by Kulthong et al., (2009). the authors administered the extract orally for 90 days at doses of 1,000,100, and $10 \mathrm{mg} / \mathrm{kg} /$ day; however, their study did not report that the extract produces a modulator effect. Some of the cytochromes studied so far include the following: 1A1 (Kulthong et al., 2009; Álvarez-González et al., 2010); 1A2 and 2B1/2B2 (Pan et al., 2011; Kulthong et al., 2009); 2C9, 2D6, and 3A4 (Ponnusankar, et al., 2011; Zhou et al., 2011). The DEX adminstered produced an increase in messenger RNA (mRNA) levels in CYP3a1; these results are in agreement with those presented by Pekthong et al. (2009), Wang \& Yeung (2011), Lee et al. (2011), Cantiello et al. (2009), Ooi et al. (2011), and Kishida et al. (2008); moreover, Kishida et al (2008) demonstrated that DEX is a selective inducer of CYP3a1, and that this induction is favored in Wistar rats. One of the strengths of the present study is that all of the groups were maintained, and that the same administration route was employed (Badal et al., 2011; Kondo et al., 2011). 


\title{
Martínez-Pérez et al., Afr J Tradit Complement Altern Med., (2017) 14 (4): 62-68
}

\author{
https://doi.org/10.21010/ajtcam.v14i4.8
}

\section{Acknowledgments}

I would like to thank the National Council of Science and Technology (CONACyT-Mexico) and the Autonomous University of Coahuila (Mexico) Center for Medical Research (CIB).

\section{Conflict of interest}

The authors state that they have no conflict of interest in terms of the publication of this work.

\section{References}

1. Agbonon, A., Eklu-Gadegbeku, K., Aklikokou, K., Gbeassor, M., Akpagana, K., Tam, T. W., Arnason, J. T., Foster, B.C. (2010). In vitro inhibitory effect of West African medicinal and food plants on human cytochrome P450 3A subfamily. J Ethnopharmacol 128(2): 390-4.

2. al-Said, M. S., Tariq, M., al-Yahya, M. A., Rafatullah, S., Ginnawi, O. T., Ageel, A.M. (1990). Studies on Ruta chalepensis, an ancient medicinal herb still used in traditional medicine. J_Ethnopharmacol 28(3): 305-12.

3. Álvarez-González, I., Mojica, R., Madrigal-Bujaidar, E., Camacho-Carranza, R., Escobar-García, D., Espinosa-Aguirre, J. J. (2010). The antigenotoxic effects of grapefruit juice on the damage induced by benzo(a)pyrene and evaluation of its interaction with hepatic and intestinal Cytochrome P450 (Cyp) 1a1. Food Chem Toxicol 49(4): 807-11.

4. Badal, S., Williams, S. A., Huang, G., Francis, S., Vendantam. P., Dunbar, O., Jacobs, H., Tzeng, T. J., Gangemi, J., Delgoda, R. (2011). Cytochrome P450 1 enzyme inhibition and anticancer potential of chromene amides from Amyris plumieri. Fitoterapia 82(2): 230-6.

5. Bastos, M. L., Lima, M. R., Conserva, L. M., Andrade, V. S., Rocha, E. M., Lemos, R. P. (2009). Studies on the antimicrobial activity and brine shrimp toxicity of Zeyheria tuberculosa (Vell.) Bur. (Bignoniaceae) extracts and their main constituents. Ann Clin Microbiol Antimicrob 8: 16.

6. Cantiello, M., Giantin, M., Carletti, M., Lopparelli, R. M., Capolongo, F., Lasserre F., Bollo, E., Nebbia, C., Martin, P. G. P., Pineau, T., Dacasto, M. (2009). Effects of dexamethasone, administered for growth promoting purposes, upon the hepatic cytochrome P450 3A expression in the veal calf. Biochem Pharmacol 77(3): 451-63.

7. Carballo, J. L., Hernández-Inda, Z. L., Pérez, P., García-Grávalos, M. D. (2002). A comparison between two brine shrimp assays to detect in vitro cytotoxicity in marine natural products. BMC Biotechnology 2: 1-5.

8. Chen, X., Sun, C. K., Han, G. Z., Peng, J. Y., Li, Y., Liu, Y. X., Lv, Y. Y., Liu, K. X., Zhou, Q., Sun, H. J. (2009). Protective effect of tea polyphenols against Paracetamol-induced hepatotoxicity in mice is significantly correlated with cytochrome P450 suppression. World J Gastroenterol 15(15): 1829-35.

9. Dally, H., Edler, L., Jager, B., Schmezer, P., Spiegelhalder, B., Dienemann, H., Drings, P., Schulz, V., Kayser, K., Bartsch, H., Risch, A. (2003). The CYP3A4*1B allele increases risk for small cell lung cancer: effect of gender and smoking dose. Pharmacogenetics 13(10): 607-18.

10. de Freitas, T. G., Augusto, P.M., Montanari, T. (2005). Effect of Ruta graveolens L. on pregnant mice. Contraception 71(1): 74-7.

11. Déciga-Campos, M., Rivero-Cruz, I., Arriaga-Alba, M., Castañeda-Corral, G., Ángeles-López, G. E., Navarrete, A. (2007). Acute toxicity and mutagenic activity of Mexican plants used in traditional medicine. J Ethnopharmacol 110(2): 334-42.

12. Di Stasi, L. C., Hiruma, C.A., Guimaraes, C.M. (1994). "Medicinal plants used in Brazilian Amazon." Fitoterapia 65: 529-540.

13. Khadhri, A., Bouali, I., Belkhir, S., Moked, R., Smiti, S., Falé, P., Araújo, M.E.M., Serralheiro, M.L.M. (2017). "In vitro digestion, antioxidant and antiacetylcholinesterase activities of two species of Ruta: Ruta chalepensis and Ruta montana." Pharm. Biol. 55(1): 101-107.

14. Keshava, C., McCanlies, E. C., Weston, A. (2004). CYP3A4 polymorphisms- potential risk factors for breast and prostate cancer: a HuGE review. Am J Epidemiol 160(9): 825-41.

15. Kishida, T., Muto, S., Hayashi, M., Tsutsui, M., Tanaka, S., Murakami, M., Kuroda, J. (2008). Strain differences in hepatic cytochrome P450 1A and 3A expression between Sprague-Dawley and Wistar rats. J Toxicol Sci 33(4): 447-57.

16. Kondo, S., Chatuphonprasert, W., Jaruchotikamol, A., Sakuma, T., Nemoto, N. (2011). Cellular glutathione content modulates the effect of andrographolide on beta-naphthoflavone-induced CYP1A1 mRNA expression in mouse hepatocytes. Toxicology 280(1-2): $18-23$.

17. Kulthong, K., Tantisira, M. H., Niwattisaiwong, N., Apipalakul, K., Chevapat, S., Lawanprasert, S. (2009). Effects of the standard extract of Centella asiatica (ECa233) on rat hepatic cytochrome P450. Thai J Pharm Sci 33: 91-100.

18. Laursen, T., Jensen, K., Moller, B. L. (2011). Conformational changes of the NADPH-dependent cytochrome P450 reductase in the course of electron transfer to cytochromes P450. Biochim Biophys Acta 1814(1): 132-8.

19. Lee, W. Y., Zhou, X., Or, P. M., Kwan, Y. W., Yeung, J. H. (2011). Tanshinone I increases CYP1A2 protein expression and enzyme activity in primary rat hepatocytes. Phytomedicine 15; 19(2): 169-76.

20. Li, Y. H., Zhang, Y. Q., Li, L., Wang, Q., Wang, N. S. (2008). Effect of Danggui and Honghua on cytochrome P450 1A2, 2C11, 2E1 and 3A1 mRNA expression in liver of rats. Am J Chin Med 36(6): 1071-81. 


\title{
Martínez-Pérez et al., Afr J Tradit Complement Altern Med., (2017) 14 (4): 62-68
}

\author{
https://doi.org/10.21010/ajtcam.v14i4.8
}

21. Liu, H. (2010). Spectral characterization and chiral interactions of plant microsomal cytochrome P450 with metolachlor and herbicide safeners. J Environ Sci Health B 45(1): 33-9.

22. Morioka, Y., Nishimura, M., Imai, T., Suzuki, S., Harada, M., Satoh, T., Naito, S. (2006). Assessment of induction of cytochrome P450 by NO-1886 (Ibrolipim), a lipoprotein lipase-promoting agent, in primary cultures of human hepatocytes and in female rat liver. Drug Metab Pharmacokinet 21(1): 19-28.

23. Mrozikiewicz, P. M., Bogacz, A., Karasiewicz, M., Mikolajczak, P. L., Ozarowski, M., Seremak-Mrozikiewicz, A. Czerry, B., Bobkiewicz-Kozlowska, T., Grzeskowiak, E. (2010). The effect of standardized Echinacea purpurea extract on rat cytochrome P450 expression level. Phytomedicine 17(10): 830-3.

24. Nazish, I., Kaskoos, R. A., Mir, S. R., Amin, S., Ali, M. (2009). Preliminary pharmacognostical standardisation of Ruta graveolens L. aerial parts. Res J Med Plant 3(2): 41-4.

25. Ooi, J. P., Kuroyanagi, M., Sulaiman, S. F., Muhammad, T. S., Tan, M. L. (2011). Andrographolide and 14-deoxy-11, 12didehydroandrographolide inhibit cytochrome P450s in HepG2 hepatoma cells. Life Sci 88(9-10): 447-54.

26. Orlita A, Sidwa-Gorycka M, Malinski E, Czerwicka M, Kumirska J, Golebiowski M., Loikowska, E., Stepnowski, P. (2008). Effective biotic elicitation of Ruta graveolens L. shoot cultures by lysates from Pectobacterium atrosepticum and Bacillus spp. Biotechnol Lett 30(3): 541-5.

27. Pan, Y., Abd-Rashid, B. A., Ismail, Z., Ismail, R., Mak, J. W., Pook, P. C. K., Er, H. M., Ong, C. E. (2011). In vitro effects of active constituents and extracts of Orthosiphon stamineus on the activities of three major human cDNA-expressed cytochrome P450 enzymes. Chem Biol Interact 190(1): 1-8.

28. Pekthong, D., Blanchard, N., Abadie, C., Bonet, A., Heyd, B., Mantion, G., Berthelot, A., Richert, L., Martin, H. (2009). Effects of Andrographis paniculata extract and Andrographolide on hepatic cytochrome P450 mRNA expression and monooxygenase activities after in vivo administration to rats and in vitro in rat and human hepatocyte cultures. Chem Biol Interact 179(2-3): 247-55.

29. Pino, O., Sánchez, Y., Rojas, M. M., Abreu, Y., Correa, T., Martínez, D., Montes de Oca, R. (2014). Composición química y actividad antibacteriana del aceite esencial de Ruta chalepensis L. Rev Protec Veg 29(3): 220-225

30. Ponnusankar, S., Pandit, S., Babu, R., Bandyopadhyay, A., Mukherjee, P. K. (2011). Cytochrome P450 inhibitory potential of Triphala- a Rasayana from Ayurveda. J Ethnopharmacol 133(1): 120-5.

31. Sarkar, M. A., Vadlamuri, V., Ghosh, S., Glover, D. D. (2003). Expression and cyclic variability of CYP3A4 and CYP3A7 isoforms in human endometrium and cervix during the menstrual cycle. Drug Metab Dispos 31(1): 1-6.

32. Schmelzer, G. H. and Gurib-Fakim, A. (2013). Plant resources of tropical Africa. Medicinal Plants $211(2): 417$ p.

33. Serrano-Gallardo, L. B. (2005). Actividad antiespasmódica de extractos de plantas medicinales en preparaciones de ileón de cobayo. Monterrey, Nuevo León, México, Universidad Autónoma de Nuevo León. Disertación Doctoral: 72.

34. Swinney, R., Hsu, S., Tomlinson, G. (2006). Phase I and Phase II enzyme polymorphisms and childhood cancer. J Investig Med 54(6): 303-20.

35. Wang, X. and J. H. Yeung (2011). Inhibitory effect of tanshinones on rat CYP3A2 and CYP2C11 activity and its structure-activity relationship. Fitoterapia 82(4): 539-45.

36. Wang, J. F., Zhang, C. C., Chou, K. C., Wei, D. Q. (2009). Structure of cytochrome p450s and personalized drug. Curr Med Chem 16(2): 232-44.

37. Zhou, C., Li, X. C., Fang, W. H., Yang, X. L., Hu, L. L., Zhou, S., Zhou, J. F. (2011). Inhibition of CYP450 1A and 3A by berberine in crucian carp Carassius auratus gibelio. Comp Biochem Physiol C Toxicol Pharmacol 154(4):360-6.

38. Zhou, S. F., Xue, C. C., Yu, X.Q., Li, C., Wang, G. (2007). Clinically important drug interactions potentially involving mechanismbased inhibition of cytochrome P450 3A4 and the role of therapeutic drug monitoring. Ther Drug Monit 29(6): 687-710. 